\title{
Efisiensi Produktifitas Wakaf Tunai (Wakaf Uang) dalam Pemberdayaan Ekonomi di Indonesia
}

\author{
Nila Saadati \\ Fakultas Hukum Islam, Konsentrasi Keuangan dan Perbankan Syariah \\ UIN Sunan Kalijaga, Yogyakarta \\ Email: nilasaadati11@yahoo.com
}

\section{A bstract}

This article aims to analyze the waqf if it is managed productively. Commonly, the existence of waqf in Indonesia is used for the mosque, school, farm, and orphanages. Thus, the existence of cash waqf is productive if it can be a solution for the community to improve the economy of the people as a form of solidarity that becomes an instrument contributed to the welfare of society.

Keywords: Cash waqf, productive endowments, efficiency, productivity

\section{A bstrak}

A rtikel ini bertujuan untuk menganalisis wakaf jika dikelola secara produktif. Sebab secara umum keberadaan wakaf di Indonesia adalah digunakan untuk masjid, musholla, sekolah, tanah pertanian, rumah yatim piatu. Dengan demikian keberadaan wakaf tunai jika dikelola secara produktif dapat menjadi solusi bagi masyarakat untuk meningkatkan perekonomian umat. , sebagai bentuk solidaritas yang menjadi instrument kontributif terhadap kesejahteraan masyarakat yang abadi (dana sosial abadi).

K ata K unci: wakaf tunai, wakaf produktif, efisiensi, produktifitas

\section{Pendahuluan}

Di masa pertumbuhan ekonomi di Indonesia yang cukup memprihatinkan saat ini, sesungguhnya peranan wakaf di samping instrumeninstrumen ekonomi Islam lainnya seperti zakat, infaq, sedekah dan lain-lain 
belum dapat dirasakan manfaatnya untuk meningkatkan taraf hidup masyarakat khususnya di bidang ekonomi.

Peruntukan wakaf di Indonesia yang kurang mengarah pada pemberdayaan ekonomi umat dan cenderung hanya untuk kepentingan ibadah khusus dapat dimaklumi, karena memang pada umumnya ada keterbatasan umat Islam tentang pemahaman wakaf, baik mengenai harta yang diwakafkan maupun peruntukannya. Wakaf bisa dijadikan sebagai lembaga ekonomi yang potensial untuk dikembangkan selama bisa dikelola secara optimal, karena institusi perwakafan merupakan salah satu aset kebudayaan nasional dari aspek sosial yang perlu mendapat perhatian sebagai penopang hidup dan harga diri bangsa. Oleh karena itu, kondisi wakaf di Indonesia perlu mendapat perhatian ekstra, apalagi wakaf yang ada di Indonesia pada umumnya berbentuk benda yang tidak bergerak dan tidak dikelola secara produktif dalam arti hanya digunakan untuk masjid, musholla, sekolah, rumah penampungan anak yatim piatu dan sebagainya.

Sejak masuknya Islam di nusantara ini, penerapan hukum Islam telah dilakukan sedikit demi sedikit bahkan secara bertahab dalam kehidupan sehari-hari umat Islam (Acmad A zhar Basyir, 2002: 2). Dalam bentuk yudisprudensi dan perundang-undangan, walaupun penerapannya seperti "malumalu" dibandingkan dengan materi hukum itu sendiri, akan tetapi dapat dipastikan bahwa penerapan hukum Islam tetap menjadi salah satu perhatian Pemerintah dan DPR melalui legislasinya. Kita lihat saja UU No.1 tahun 1974, tentang perkawinan, UU No.4 tahun 1979, tentang Kesejahteraan A nak, UU No.38 tahun 1999 tentang Pengelolaan Zakat dan UU No.41 tahun 2004 tentang Wakaf.

Undang-undang yang disebutkan terakhir, kehadirannya merupakan angin segar tentang pengelolaan wakaf di Indonesia. K eberadaan Undangundang ini tentu sangat berbeda sekali dengan aturan pendahulunya tentang wakaf seperti Peraturan Pemerintah No.28 tahun 1977 dan buku III Kompilahi Hukum Islam (K HI) tahun 1991. Terutama tentang harta wakaf, dimana UU No.41 tahun 2004 menyebutkan bahwasannya harta wakaf terdiri dari benda bergerak dan benda tidak bergerak. Termasuk didalamnya uang tunai, logam mulia, surat berharga, kendaraan, hak atas kekayaan intelektual, hak sewa dan benda bergerak lainnya sesuai dengan ketentuan syariah dan 
peraturan perundang-undang yang berlaku, padahal PP No.28 tahun 1977 membatasi wakaf hanya pada benda yang tidak bergerak (tanah) dan $\mathrm{KHI}$ membatasi wakaf pada benda tak bergerak dan bergerak bukan uang, selama mempunyai daya tahan yang tidak habis sekali pakai dan bernilai menurut ajaran Islam (Farid Wadjdy dan Mursyid 2007: 2-3).

Pengelolaan dan pengembangan wakaf yang ada di Indonesia diperlukan komitmen bersama pemerintah, ulama dan masyarakat. Selain itu juga harus dirumuskan kembali mengenai berbagai hal yang berkenaan dengan wakaf, termasuk harta yang diwakafkan, peruntukkan wakaf dan nadzir serta pengelolaan wakaf secara profesional. Selanjutnya wakaf harus diserahkan kepada orang-orang atau suatu badan khusus yang mempunyai kompetensi memadai sehingga bisa mengelola secara profesional dan amanah.

Wakaf Tunai merupakan pranata ekonomi Islam yang memiliki peranan penting dalam perkembangan masyarakat, baik dalam bidang pendidikan dan keagamaan maupun dalam bidang ekonomi dan sosial. Lembaga ini walaupun tidak termasuk sumber keuangan publik yang primer, tetapi jika dibandingkan dengan zakat, infaq dan sedekah, memiliki kekuatan ekonomi yang kokoh, karena dana yang digunakan untuk mendukung berbagai proyek keagamaan dan sosial adalah keuntungan dan manfaatnya, sementara danazakat, infaq dan sedekah (ZIS) adalah asetnya sehingga bersifat komsumtif.

Di tengah problem sosial masyarakat Indonesia dan tuntutan akan kesejahteraan ekonomi akhir-akhir ini keberadaan lembaga wakaf menjadi sangat strategis. Di samping sebagai salah satu aspek ajaran Islam yang berdimensi spiritual, wakaf tunai juga merupakan ajaran yang menekankan pentingnya kesejahteraan ekonomi (dimensi sosial) (Tim Dirjen Bimas Islam dan Penyelengaraan Haji Depag-RI, 2005: 1).

\section{Landasan teori wakaf}

M uhammad A I-K hatib mengemukakan bahwasannya wakaf diambil dari bahasa Arab "waqafa" itu menurut bahasa berarti menahan atau berhenti, di tempat. Secara harfiyah bermakna "pembatasan" atau "Iarangan". Sehingga kata waqf (Jama': A uqaf) di gunakan dalam Islam untuk maksud "pemilikan dan pemeliharaan" harta benda tertentu untuk kemanfaatansosial 
tertentu yang ditetapkan dengan maksud mencegah penggunaan harta wakaf tersebut diluar tujuan khusus yang telah ditetapkan tersebut (Farid Wadjdy dan M ursyid 2007: 29-30).

Sedang menurut syara' wakaf berarti menahan harta dan memeberikan manfaatnya di jalan Allah. Dalam hukum Islam, wakaf berarti menyerahkan suatu hak milik yang tahan lama (zatnya). kepada seseorang atau nadzir (penjaga wakaf), baik berupa perorangan maupun badan pengelola, dengan ketentuan bahwa hasil atau manfaatnya digunakan untuk hal-hal yang sesuai dengan ajaran syari' at Islam. M elalui wakaf diharapkan akan terjadi proses distribusi manfaat bagi masyarakat secara lebih luas, dari manfaat pribadi (private benefit) menuju manfaat masyarakat (sosial benefit).

\section{Pengertian wakaf tunai}

Pengertian wakaf sebagaimana tersebut dalam Pasal 1 UndangUndang Nomor 41 Tahun 2004 tentang Wakaf, diperluas Iagi berkaitan dengan Harta Benda Wakaf (obyek wakaf) yang diatur dalam Pasal 16 ayat (1) yang menyatakan Harta B enda Wakaf meliputi : (a) B enda tidak bergerak, dan (b) Benda bergerak.

Selanjutnya yang dimaksud wakaf benda bergerak, salah satunya adalahuang. (Pasal 16 ayat (3) huruf a Undang-Undang Nomor 41 Tahun 2004 tentang Wakaf). Dengan demikian yang dimaksud wakaf tunai adalah wakaf yang dilakukan seseorang, kelompok orang dan lembaga atau badan hukum dalam bentuk uang. Juga termasuk kedalam pengertian uang adalah surat-surat berharga, seperti saham, cek dan lainnya (Tim Dirjen Bimas Islam dan Penyelengaraan Haji Depag-RI, 2005: 1).

Sebagai contoh apabila wakaf tunai dapat diimplementasikan maka ada dana potensial yang sangat besar yang bisa dimanfaatkan untuk pemberdayaan dan kesejahteraan ummat. Jika saja terdapat 1 juta saja masyarakat M uslim yang mewakafkan dananya sebesar R 150.000 , maka akan diperoleh pengumpulan dana wakaf sebesar Rp 150 milyar setiap bulan (Rp 1,6 trilyun/ tahun). Jika diinvestasikan dengan tingkat return 10 persen per tahun maka akan diperoleh penambahan dana wakaf sebesar Rp 15 milyar setiap bulan (Rp 160 milyar/tahun). 


\section{Dasar Hukum Wakaf Uang}

Wakaf termasuk infaq fi sabilillah, maka dasar yang digunakan para ulama dalam menerangkan konsep wakaf ini didasarkan pada keumuman ayat-ayat al-Quran yang menjelaskan tentang infaq fi sabilillah. Di antara ayat-ayat tersebut adalah QS Ali Imron [3] : 92:

لن تنالوا البر حتى تنفقوا مما تحبون وما تنفقوا من شىء فإن الله به عليم .

"Kamu sekali-kali tidak akan sampai kepada kebaikan (yang sempurna) sebelum kamu menafkahkan sebahagian harta yang kamu cintai, dan apa saja yang kamu nafkahkan maka sesungguhnya Allah mengetahuinya".

Dalam QS AI-Baqoroh [2] : 261-262

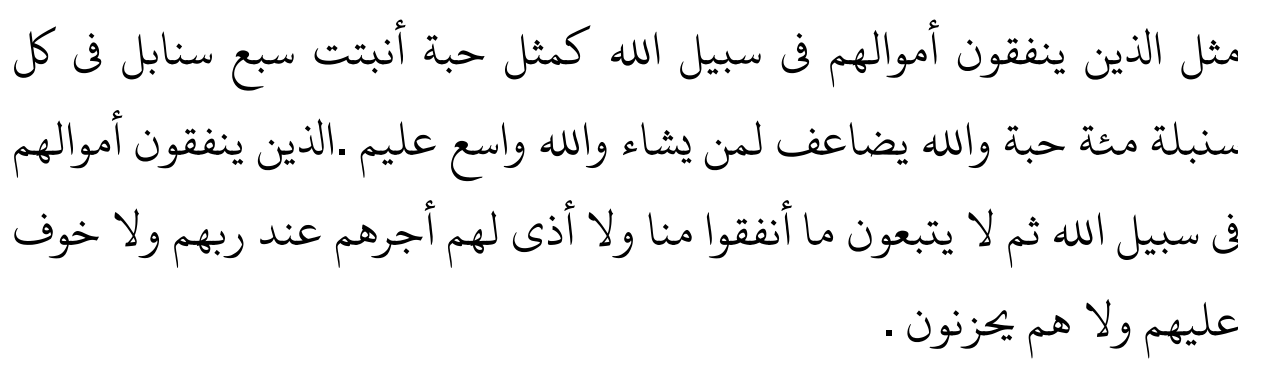

"Perumpamaan (nafkah yang dikeluarkan oleh) orang-orang yang menafkahkan hartanya di jalan A llah adalah serupa dengan sebutir benih yang menumbuhkan tujuh bulir, pada tiap-tiap bulir seratus biji. A llah melipat gandakan (ganjaran) bagi siapa yang Dia kehendaki. Dan Allah Maha L uas (karuniaNya) lagi M aha M engetahui. Orangorang yang menafkahkan hartanya di jalan Allah, kemudian mereka tidak mengiringi apa yang dinafkahkannya itu dengan menyebutnyebut pemberiannya dan dengan tidak menyakiti (perasaan si penerima), mereka memperoleh pahala di sisi Tuhan mereka. Tidak ada kekhawatiran terhadap mereka dan tidak (pula) mereka bersedih hati" 
K emudian dalam QS A I-Baqoroh [2] : 267

يا أيها الذين آمنوا أنفقوا من طيبات ما كسبتم ومما أخرجنا لكم من الأرض ولا تيمموا الخبيث منه تنفقون ولستم بآخذيه إلا أن تغمضوا فيه واعلموا أن الله غنى حميد .

"Hai orang-orang yang beriman, nafkahkanlah (di jalan Allah) sebagian dari hasil usahamu yang baik-baik dan sebagian dari apa yang Kami keluarkan dari bumi untuk kamu. Dan janganlah kamu memilih yang buruk-buruk lalu kamu nafkahkan daripadanya, padahal kamu sendiri tidak mau mengambilnya melainkan dengan memicingkan mata terhadapnya. Dan ketahuilah, bahwa Allah Maha Kaya lagi Maha Terpuji."

Ayat-ayat tersebut di atas menjelaskan tentang anjuran untuk menginfakkan harta yang diperoleh untuk mendapatkan pahala dan kebaikan. Di samping itu, ayat 261 surat al-Baqarah telah menyebutkan pahala yang berlipat ganda yang akan diperoleh orang yang menginfakkan hartanya di jalan Allah.

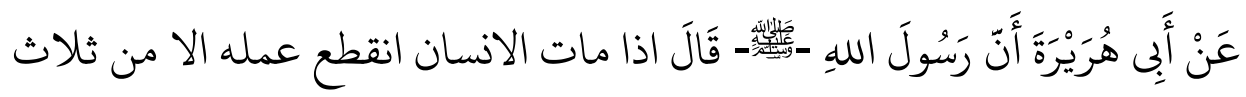
صدقة جارية أو علم ينتفع به أو ولد صالح يدعو له اله

"Diriwayatkan dari A bu Hurairah ra, bahwasanya Rasulullah saw bersabda: A pabila anak adam meninggal dunia, maka putuslah amalnya kecuali tiga perkara: shodaqoh jariyah (wakaf), ilmu yang bermanfaat dan anak sholeh yang mendoakan orang tuanya." (HR. M uslim dan HR. A hmad)

عن عبد الله بن عمر أن عمر رضى الله عنه أنى النبى صلى الله عليه وسلم وكان قد ملك مائة سهم من خيبر فقال قد أصبت مالا لم أصب مثله وقد أردت أن أتقرب به إلى الله تعالى فقال حبس الأصل وسبل الثمرة 
"Bahwa Umar r.a. telah berkata kepada Nabi SAW, 'Sesungguhnya saya mempunyai seratus saham di Khaibar, belum pernah saya mempunyai harta yang lebih saya cintai daripada itu, sesungguhnya saya bermaksud hendak menyedekahkannya", Jawab Nabi SAW, "Engkau tahan pokoknya (asalnya) dan sedekahkan buahnya". (Hadis riwayat A $n-N$ asa'i dan Ibnu Majah)

Dalam riwayat lain:

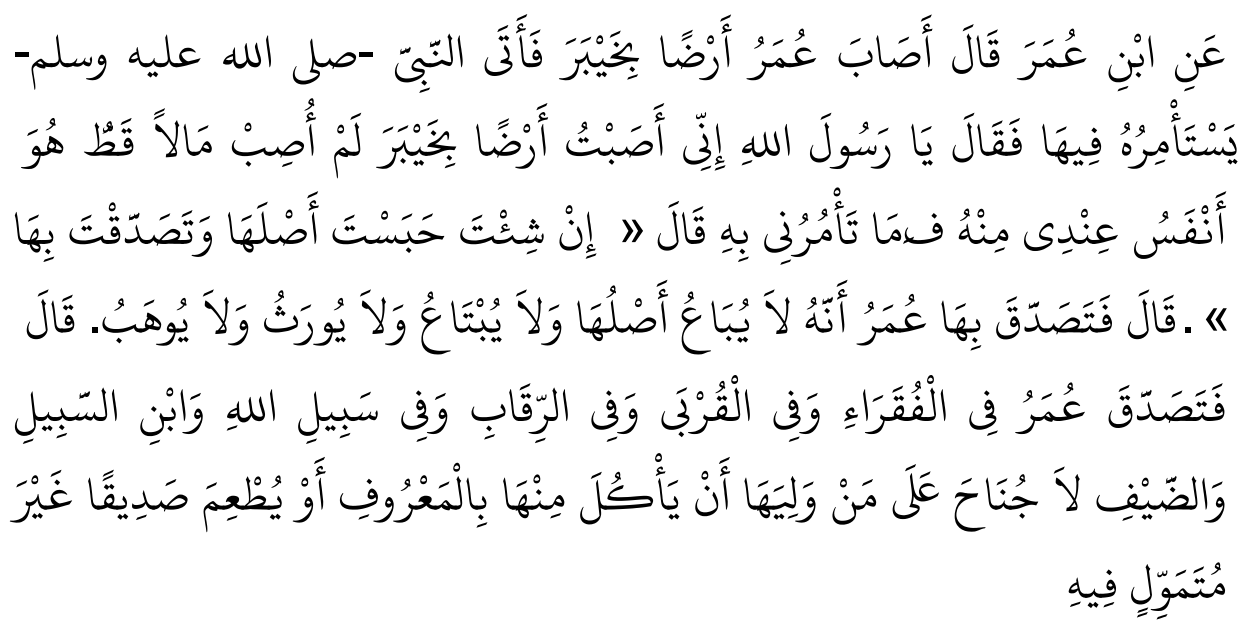

"Diriwayatkan dari Ibnu U mar ra, dia berkata: U mar telah mendapatkan sebidang tanah di K haibar, lalu dia datang kepada Nabi saw untuk meminta pertimbangan tentang tanah itu, kemudian ia berkata: Wahai Rasulullah, sesungguhya aku mendapatkan sebidang tanah di K haibar, dimana aku tidak mendapatkan harta yang lebih berharga bagiku selain dari padanya; maka apakah yang hendak engkau perintahkan kepadaku sehubungan dengannya? Rasulullah saw berkata kepada Umar: Jika engkau suka tahanlah tanah itu dan engkau sedekahkan manfaatnya. L alu U mar pun menyedekahkan manfaat tanah itu dengan syarat tanah itu tidak akan dijual, tidak akan dihibahkan dan tidak akan diwariskan. Tanah itu dia wakafkan kepada orang-orang fakir kaum kerabat, hamba sahaya, sabilillah, Ibnu sabil, dan tamu, dan tidak ada halangan bagi orang yang mengurusnya untuk memakan sebagian darinya dengan cara yang ma'ruf dan memakannya tanpa menganggap bahwa tanah itu miliknya sendiri."(HR. M uslim, Shahih M uslim)

Hadist di atas merupakan dasar umum disyariatkannya wakaf dan juga dipakai oleh Majelis Ulama Indonesia (MUI) dalam fatwa kebolehan 
wakaf uang. Hadist pertama mendorong manusia untuk menyisihkan sebagian rezekinya sebagai tabungan akhirat dalam bentuk sedekah jariyah. U ang merupakan sarana yang paling mudah untuk disedekahkan.

Pada hadist ketiga, wakaf uang menjadikan hadist ini sebagai pijakan hukum karena menganggap bahwa wakaf uang memiliki hakekat yang sama dengan wakaf tanah, yakni harta pokoknya tetap dan hasilnya dapat dikeluarkan. Dengan mekanisme wakaf uang yang telah ditentukan, pokok harta akan dijamin kelestariannya dan hasil usaha atas penggunaan uang tersebut dapat dipakai untuk mendanai kepentingan umat.

\section{Perdebatan pendapat di kalangan ulama}

M enurut Monzer Kahf (2008) hukum wakaf tunai telah menjadi perhatian para fuqaha'. Beberapa sumber menyebutkan bahwa wakaf uang telah dipraktikkan oleh masyarakat yang menganut madzhab Hanafi. Wahbah az-Zuhaili juga mengungkapkan bahwa madzhab Hanafi membolehkan wakaf tunai atas dasar Istihsan bi al-'Urfi, karena sudah banyak masyarakat yang melakukannya. Madzhab Hanafi memang berpendapat bahwa hukum yang ditetapkan berdasarkan 'urf (adat kebiasaan) mempunyai kekuatan yang sama dengan hukum yang ditetapkan berdasarkan nash (teks). Dasar argumentasi madzhab Hanafi adalah hadis yang diriwayatkan oleh A bdullah bin Ma'ud, r.a:

"A pa yang dipandang baik oleh kaum Muslimin, maka dalam pandangan Allah adalah baik, dan apa yang dipandang buruk oleh kaum Muslimin maka dalam pandangan Allah pun buruk".

I mam A z-Zuhri, salah seorang ulama terkemuka dan peletak dasar kodifikasi hadits (tadwin al-hadits) mengeluarkan fatwa yang berisi anjuran melakukan wakaf dinar dan dirham untuk pembangunan sarana dakwah, sosial, dan pendidikan umat Islam. A dapun caranya adalah dengan menjadikan uang tersebut sebagai modal usaha kemudian menyalurkan keuntungannya sebagai wakaf.

Sedangkan Ibn A bidin mengemukakan bahwa wakaf tunai yang dikatakan merupakan kebiasaan yang berlaku di masyarakat adalah kebiasaan yang berlaku di wilayah Romawi, sedangkan di negeri lain wakaf tunai bukan 
merupakan kebiasaan. Karena itu Ibn A bidin berpandangan bahwa wakaf tunai tidak boleh atau tidak sah. Yang juga berpandangan bahwa wakaf tunai adalah madzhab Syafi'i. M enurut AI-Bakri, madzhab Syafi'i tidak membolehkan wakaf tunai, karena dinar dan dirham (uang) akan lenyap ketika dibayarkan sehingga tidak ada lagi wujudnya.

Dari beberapa penjelasan di atas, secara ringkas dapat disimpulkan bahwa ulama yang membolehkan wakaf dengan uang tunai beralasan dengan:

a. Pendapat Imam Az-Zuhri yang menyatakan bahwa mewakafkan dinar hukumnya boleh, dengan cara menjadikan dinar tersebut sebagai modal usaha kemudian keuntungannya disalurkan pada mauquf 'alaih.

b. Mutaqaddimin dari ulama madzhab Hanafi membolehkan wakaf uang dinar dan dirham atas dasar istihsan bi al-'urfi.

Sedangkan alasan ulama yang tidak memperbolehkan wakaf dengan uang tunai beralasan bahwa:

a. Bahwa uang zatnya bisa habis dengan sekali pakai. Uang hanya bisa dimanfaatkan dan dibelanjakan sehingga bendanya lenyap. Padahal inti dari wakaf adalah pada kesinambungan hasil dari modal / harta yang tetap. Oleh karena itu ada persyaratan agar benda yang diwakafkan harus tahan lama dan tidak habis ketika dipakai.

b. Bahwa uang diciptakan sebagai alat tukar, bukan untuk ditarik manfaatnya dengan mempersewakan zatnya.

\section{Undang-Undang Negara Republik Indonesia Nomor 41 Tahun 2004, Pasal 16}

(1) Harta benda wakaf terdiri dari:
a) benda tidak bergerak; dan
b) benda bergerak.

(2) Benda tidak bergerak sebagaimana dimaksud pada ayat (1) huruf a meliputi:

a) hak atas tanah sesuai dengan ketentuan peraturan perundangundangan yang berlaku baik yang sudah maupun yang belum terdaftar; 
b) bangunan atau bagian bangunan yang berdiri di atas tanah sebagaimana dimaksud pada huruf a;

c) tanaman dan benda lain yang berkaitan dengan tanah; hak milik atas satuan rumah susun sesuai dengan ketentuan peraturan perundangundangan yang berlaku;

d) benda tidak bergerak lain sesuai dengan ketentuan syariah dan peraturan perundang undangan yang berlaku.

(3) Benda bergerak sebagaimana dimaksud pada ayat (1) huruf b adalah harta benda yang tidak bisa habis karena dikonsumsi, meliputi:
a) uang;
b) logam mulia;
c) surat berharga;
d) kendaraan;
e) hak atas kekayaan intelektual;
f) hak sewa; dan
g) benda bergerak lain sesuai dengan ketentuan syariah dan peraturan perundang.undangan yang berlaku.
Di Negara Indonesia, wakaf uang sudah diatur pelaksanaannya melalui Peraturan Pemerintah (PP) Republik Indonesia NO 42 tahun 2006.

\section{Fungsi wakaf tunai}

Wakaf Tunai yang didefinisikan sebagai aset yang disumbangkan untuk kemanusiaan dalam jangka waktu yang relatif lama, mempunyai fungsi ritual dan sosial ekonomi.

a. Fungsi Ritual

Wakaf adalah sebagai implementasi iman seseorang dalam bentuk implementasi iman seseorang dalam bentuk kesadaran beramal shaleh yang dapat diharapkan pahalanya mengalir terus menerus (Shadaqah Jariyyah) hingga yang bersangkutan telah meninggal dunia.

b. Fungsi Sosial Ekonomi

Sebagai bentuk solidaritas yang menjadi instrument kontributif terhadap kesejahteraan masyarakat yang abadi dana sosial abadi (Mukhlisin Muzarie, 2011: 1). 


\section{Rukun dan syarat wakaf}

Sebagaimana akad muamalah pada umumnya prosesi wakaf juga dituntut terpenuhinya beberapa unsur baik sebelum wakaf dilakukan syarat maupun ketika prosesi wakaf tersebut dilaksanakan rukun (A bdul Ghofur A nshori, 2005: 25).

Oleh Hukum Indonesia sendiri dan menurut Abdul Ghofur Anshori (2005) rukun prosesi wakaf ini kemudian diklasifikasikan ke dalam unsurunsur berikut:

1. Wakif, orang yang berwakaf,

2. Nadzir, Pengelola wakaf,

3. Maukuf, harta yang diwakafkan,

4. Sighat, akad wakaf / pernyataan ikrar wakaf.

5. Mauquf 'alaih, tempat kemana diwakafkan harta itu/ tujuan wakaf,

6. Jangka waktuwakaf yang tidak terbatas.

Eksistensi Nadzir dan jangka waktu yang tidak terbatas merupakan penambahan rukun yang terdapat pada prosesi wakaf di Indonesia.

\section{Tehnik mobilisasi dana wakaf tunai}

Wakaf Tunai merupakan salah satu usaha yang tengah berkembang dalam rangka meningkatkan peran wakaf dalam bidang ekonomi. Karena Wakaf Tunai memiliki kekuatan yang bersifat umum dimana setuap orang bias menyumbangkan harta tanpa batas-batas tertentu. Demikian juga fleksibelitas wujud dan pemanfaatannya yang dapat menjangkau seluruh potensi ekonomi untuk dikembangkan.

Beberapa contoh atau model di bawah ini dapat dijadikan pokok pilar guna mobilisasi wakaf tunai menurut Drs. H. Farid Wadjdy, M. Pd dan M ursyid, M. SI, 2007:92 adalah:

a. Model Mustafa Edwin Nasution

Model mobilisasi wakaf tunai yang ditawarkan adalah dengan menarik secara langsung ataupun tidak setiap gaji para pegawai bank yang bekerja pada pemerintah, bidang swasta, ataupun bidang ekonomi lainnya mengingat berdasar hasil penelitian PIRAC bahwa sector pendidikan, 
keagamaan dan pelayanan social adalah bidang yang paling disukai perusahaan di Indonesia dalam menyumbang.

Dengan cara pendekatan lewat pengurus organisasi "Kerohanian Islam". A kan tetapi persoalan atau kendala yang terjadi sekarang adalah bagaimana nadzir wakaf dapat meyakinkan pihak perusahaan, instansi pemerintah dan lain-lain tentang pentingnya melakukan tanggung jawab social dengan berwakaf.

b. Model Social Investment Bank Limited (SIBL)

Model SIBL sebenarnya merupakan gagasan wakaf tunai yang dipopulerkan oleh M. A. Mannan, seorang ekonom kebangsaan Bangladhes. Gagasan SIBL adalah dengan mengemas mekanisme instrument $C$ ash Waqf Certificate dan merupakan kombinasi alternative solusi mengatasi krisis kesejahteraan yang di tawarkan oleh M. U mar Chapra dengan harapan SIBL menjadi alternative peningkatan pendapatan bagi jutawan warga Negara miskin.

Operasionalkerja dari Cash Waqf Certificate adalah dengan menerbitkan sertifikat dengan nilai nominal yang berbeda-beda. A spek inilah yang sebernarnya yang menjadi keunggulan wakaf tunai dibandingkan harta tetap lainnya, karena besarnya dapat menyesuaikan kemampuan kantong calon wakif.

c. Model-model Mobilisasi Lain

Pertama, dengan menggalang animo masyarakat melalui partisipasi aktif untuk berbagi kebahagiaan dengan saudaranya dalam menikmati pendidikan, kesehatan, dan kesejahteraan yang layak. M elalui media massa baik elektronik maupun cetak seperti yang telah dilakukan oleh Dompet Dhuafa Republika, Dompet A mal Pikiran Rakyat, SCTV dengan Pundi A malnya, TPI peduli dan Iain-lain.

Kedua, dengan menyelenggarakan sebuah kegiatan khusus seperti konser usik, pameran, dan Iain-lain yang dijadikan ajang promosi. Untuk kegiantan seperti ini sangat baik jika menghadirkan Da'I-da'I kondang baik local maupun nasional atau artis-artis naik daun lainnya.

$K$ etiga, dengan menggunakan pendekatan tangan pemerintah terutama untuk melakukan pajak (Tax Deduction) kepada wakif perorangan 
Efisiensi Produktifitas Wakaf Tunai (Wakaf Uang) dalam Pemberdayaan...

maupun perusahaan.Pengurangan pajak ini penting mengingat hasil penelitian PIRAC menyebutkan bahwa 37\% perusahaandari 226 perusahaanyang diteliti menyatakan bahwa mereka akan menaikkan jumlah sumbangan. Jika ada kebijakan pengurangan pajak.

\section{Model pengelolaan wakaf tunai menurut Monzer $\mathrm{Kahf}$}

Gagasan untuk menginvestasikan dana wakaf mislanya untuk mengkonstruksi harta yang bergerak dapat diwakafkan atau untuk meninggalkan modal harta tetap wakaf tidak dibahas dalam fikh klasik. Kahf membedakan model investasi wakaf dalam dua model, model pembiayaan harta wakaf tradisional dan model pembiayaan secara institusional Monzer Kahf, 2008:251).

1. Model pembiayaan harta wakaf secara tradisional.

Dalam buku-buku figh klasik menjelaskan bahwa pembiayaan harta wakaf tradisional terdapat lima model pembiayaan rekonstruksi harta wakaf, yaitu pinjaman, Hukr (K ontrak sewa jangka panjang dengan pembayaran Lump Sumyang cukup besar di muka), Al-Ijaratain (Sewa dengan dua pembayaran), M enambah harta wakaf baru, dan penukaran pengganti (substitusi) harta wakaf.

M odel substitusi, yaitu model pertukaran harta wakaf yang satu dengan yang lainnya, sebab harta wakaf yang awal sudah lagi tidak dapat dipakai atau kurang bermanfaat. Secara prinsip pertukaran ini dilakukan karena untuk bisa memproduktifkan harta wakaf.

2. Model pembiayaan secara institusional.

Sesuai dengan perkembangan zaman maka fikh juga harus berkembang yang sesuai dengan keuangan islami. Harta wakaf dapat diinvestasikan guna membiayai proyek-proyek yang menguntungkan. Yang harus diperhatikan dalam menginvestasikan dana wakaf dalam bentuk tunai harus berpegang teguh pada prinsip-prinsip investasi islami, yaitu prinsip berbagi hasil, resiko, jual beli, dan sewa.

Investasi dana wakaf dengan beragam modelnya sebaiknya dikerjakan $\mathrm{Nadzir}$ yang professional. Menurut fikh ada dua pandangan posisi nadzir dalam kaitannya dengan masalah wakaf. Pertama, pendapat yang 
menagatakan bahwa nadzir adalah penerima, penyalur, sekaligus pengelola harta (dana) wakaf. Kedua, pendapat menyatakan bahwa Nadzir hanyalah sebagai penerima dan penyalur dana wakaf, sedangkan pengelolaannya harus dipisahkan agar menghindari adanya kemungkinan negative.

M unculnya bank-bank syari'ah membuat kalangan umat muslim membuat antusias untuk ikut menyertakan dananya agar produktif. U tamanya pengelolaan dana wakaf secara produktif. Dalam bentuk wakaf tunai pihak bank dapat langsung mengelola dana, mengembangkannya, dan menyalurkan dana tersebut sesuai tujuan yang dimaksudkan wakif atau pihak bank.

Lembaga apapun yang akan mengelola dana wakaf tersebut harus memenuhi persyaratan diantaranya ialah:

1. Profesional,

2. Transparan,

3. Dapat dipertanggungjawabkan.

\section{Potensi wakaf tunai di Indonesia}

M enurut M. U mar. Chapra, (2001: 311) bahwa diantara dasar utama untuk mecapai pertumbuhan ekonomi yang berkesinambungan adalah adanya tingkat tabungan, investasi, kerja keras dan kesungguhan. Dan potensi wakaf tunai yang digunakan untuk investasi bisnis seperti difatwakan M uhammad Ibnu Abdulah Al-A nshari akan mampu meningkatkan pertumbuhan ekonomi suatu Negara, yaitu dengan mentransformasikan tabungan masyarakat menjadi model investasi.

M ustafa Edwin Nasution seperti dikutip Supriyanto Yudi (Tim Dirjen Bimas Islam dan Penyelenggara Haji Depag RI, 2005) pernah menghitung bahwa potensi wakaf tunai dalam setahun bias terhimpun dana Rp 3 Trilyun bila dimobilisasi. Lebih lanjut M ustafa mengatakan bahwa dana Rp 3 Trilyun ini dapat menutupi $10 \%$ utang Indonesia kepada IMF tiap tahunnya. Secara sederhana perhitungan M ustafa tersebut dapat dilihat pada tabel di bawah ini. 
Tabel 1

Potensi Wakaf Tunai

\begin{tabular}{ccllll}
\hline No & $\begin{array}{c}\text { Banyaknya } \\
\text { Wakaf (Orang) }\end{array}$ & $\begin{array}{c}\text { Banyaknya Gaji } \\
\text { dibayar /bulan (Rp) }\end{array}$ & $\begin{array}{c}\text { Nominasi Wakaf } \\
\text { /bulan (Rp) }\end{array}$ & $\begin{array}{c}\text { Potensi Wakaf } \\
\text { /bulan (Rp) }\end{array}$ & $\begin{array}{c}\text { Potensi Wakaf } \\
\text { /Tahun (Rp) }\end{array}$ \\
\hline 1 & 4.000 .000 & 500.000 & 5.000 & 20 Milyar & 240 Milyar \\
2 & 3.000 .000 & 1-2 Juta & 10.000 & 30 Milyar & 360 Milyar \\
3 & 2.000 .000 & 2-5 Juta & 50.000 & 100 Milyar & 1,2 Trilyun \\
4 & 1.000 .000 & 5-10 Juta & 100.000 & 100 Milyar & 1,2 Trilyun \\
\hline POTENSI WAKAF & & & 250 Milyar & 3 Trilyun \\
\hline
\end{tabular}

Hitungan serupa pernah diungkapkan oleh Tulus dan Pengawas Badan Wakaf Kota Bekasi Siswadi. A sumsi Tulus dan Siswadi sangat sederhana, dari 160 Juta muslim di Indonesia katakana yang berkemampuan menjadi wakif 50 Juta orang, dengan kemampuan setiap orang berwakaf sebesar Rp 5000 dalam 1 tahun terkumpul 3 Trilyun (Drs. H. Farid Wadjdy, M. Pd dan M ursyid, M. SI, 2007: 138).

A ngka-angka diatas bukankah sangat fantastis, bayangkan kalau nominal tersebut diinvestasikan ke dalam sector riil dan membantu usaha kecil menengah (UKM), berapa sector rill yang dapat menjalankan? Berapa UKM yang bias hidup dari hasil wakaf? Bahkan dana perdayakan ekonomi umat, pendidikan seperti A I-A zhar. A kan tetapi persoalannya sekarang adalah bagaimana menggali potensi ekonomi wakaf secara maksimal?

\section{Praktik wakaf tunai di Modern Darussalam Gontor}

Infaq wali santri yang ditujukan oleh pondok di klaim sebagai wakaf, dengan alasan dana tersebut tidak secara langsung digunakan untuk operasional pondok, tetapi menjadi asset pondok yang selanjutnya diberdayakan melalui unit-unit usaha milik pondok. Sumber infaq yang diperoleh dari wali santri jumlahnya cukup besar.

Dari Data pendaftaran Capel dan Santri Baru tahun 2007 dan 2008, Setiap wali santri pada awal tahun memberikan infaq kepada beberapa komponen diantaranya uang pangkal, uang penambahan bangunan, pembangunan kampus baru, kesehatan, administrasi dan kepanitiaan jumlahnya Rp 
1.950.000,-(satu juta sembilan ratus lima puluh ribu rupiah). Jumlah wali santri yang memberikan infaq tahun 2007 dari capel sebanyak 4000 orang mencapai 7,8 milyar dan dari santri baru sebanyak 3000 orang mencapai 5,84 milyar serta dari santri lama sebanyak 10.900 orang mencapai 10,355 milyar.

Pada tahun 2008 jumlah infaq naik secara kumulatif dari berbagai komponen seperti tersebut diatas sehingga dari capel dan santri baru masing masing sebesar Rp 2. 420.000.- (Dua juta empat ratus dua puluh ribu rupiah). Dan dari santri lama Rp 1.220.000,- (Satu juta dua ratus dua puluh ribu rupiah).sehingga memperoleh infaq dari capel sebesar 9,68 milyar, dari santri baru 7,26 milyar dan dari santri lama sebesar 13,298 milyar.

Tabel 2

Wakaf Tunai di Modern Darussalam Gontor

\begin{tabular}{clcc}
\hline No & \multicolumn{1}{c}{ Sumber } & Jumlah/2007 & Jumlah/2008 \\
\hline 1 & Capel 4000 & $7.800 .000 .000,00$ & $9.680 .000 .000,00$ \\
2 & Siswa Baru 3000 & $5.850 .000 .000,00$ & $7.260 .000 .000,00$ \\
3 & Siswa Lama 10.900 & $10.335 .000 .000,00$ & $13.298 .000 .000,00$ \\
\hline Jml & Capel/siswa 17.900 & $24.005 .000 .000,00$ & $30.238 .000 .000,00$ \\
\hline
\end{tabular}

Wakaf yang berasal dari infaqwali santri cukup besar jumlahnya mencapai puluhan milyar.jumlah ini diprediksi setiap tahun akan terus meningkat sesuai dengan program pondok yang telah direncanakan.

Wakaf uang selain dari infaq diperoleh dari iuran santri yang masuk ke pondok setiap bulan, sebagaimana halnya ifaq, diklaim sebagai wakaf. A lasannya karena iuran tersebut tidak langsung digunakan untuk membiayai anggaran rutin pondok, tetapi dimasukkan kedalam asset pondok yang akan diberdayakan melalui unit-unit usaha milik pondok (Dr. KH. Mukhlisin M uzarie, 2011: 87).

A dapun contoh sektor produktif yang dikelola pondok yang bersumber dari wakat uang adalah:

a. Koperasi Pelajar (Ko-Pel)

b. Cafetaria Pondok 
c. Pabrik Roti

d. Pabrik Susu

e. Perkebunan

f. Dan lain sebagainya.

\section{Wakaf Uang pada Tabung Wakaf Indonesia (TWI) Dompet Dhuafa Republika}

M ekanisme yang dilakukan Tabung Wakaf Indonesia (TWI) dalam mengelola dana wakaf uang dapat dilihat dari beberapa aspek yakni penghimpunan dana wakaf, manajemen investasi serta pendistribusiannya kepada mauquf alaih.

Kegiatan penghimpunan harta benda wakaf dilakukan oleh TWI dari para wakif yang mempercayakan harta bendanya untuk diwakafkan dengan menunjuk TWI selaku nazhirnya. M enurut Dian M asyita dalam laporan penelitiannya, dalam pengelolaan wakaf uang sektor fundraising dana wakaf uang adalah salah satu model yang dapat diterapkan. Tanggung jawab pada sektor ini adalah mengumpulkan dana wakaf uang dari wakif kemudian mendistribusikannya pada investasi portofolio. Keuntungan dari investasi didistribusikan pada program pengentasan kemiskinan. Keuntungan yang akan didistribusikan tergantung pada permintaan wakif, seperti pendidikan, infrastruktur, rehabilitasi keluarga, kesehatan, dan sanitasi kesehatan publik. Dalam sektor peningkatan wakaf uang, ada beberapa hubungan sebab akibat antara orang kaya yang mempunyai potensi sebagai wakif, pengumpulan dana wakaf uang, investasi dana ke berbagai portofolio, dan mendapatkan keuntungan dari investasi yang akan didistribusikan pada orang miskin.

Bersumber dari situs resmi Badan Wakaf Indonesia bahwa benda bergerak yang dapat diwakafkan yaitu:

1. Uang

2. Logam Mulia

3. Surat B erharga

4. Kendaraan

5. Hak atas K ekayaan Intelektual

6. Hak Sewa 
7. Benda bergerak lain sesuai dengan ketentuan syariah dan peraturan perundang-undangan yang berlaku sesuai (Pasal 16 ayat 3, UU No. 41 tahun 2004).

Di antara bentuk pengelolaan wakaf produktif yang dilakukan TWI adalah dengan menyalurkan dana wakaf ke berbagai sector produktif yakni wakaf peternakan, pertanian, perkebunan, perdagangan, wakala (penjualan dinar dan dirham), dan sarana niaga.

\section{Penutup}

Wakaf adalah instrumen ekonomi Islam yang unik yang Berdasarkan fungsinya pada unsur kebajikan (birr), kebaikan (ihsan) dan persaudaraan (ukhuwah). Wakaf tunai dapat diimplementasikan maka ada dana potensial yang sangat besar yang bisa dimanfaatkan untuk pemberdayaan dan kesejahteraan ummat.

Wakaf Tunai merupakan pranata ekonomi Islam yang memiliki peranan penting dalam perkembangan masyarakat, baik dalam bidang pendidikan dan keagamaan maupun dalam bidang ekonomi dan sosial. Lembaga ini walaupun tidak termasuk sumber keuangan publik yang primer, tetapi jika dibandingkan dengan zakat, infaq dan sedekah, memiliki kekuatan ekonomi yang kokoh, karena dana yang digunakan untuk mendukung berbagai proyek keagamaan dan sosial adalah keuntungan dan manfaatnya, sementara danazakat, infaq dan sedekah (ZIS) adalah asetnya sehingga bersifat komsumtif.

Jika di Indonesia banyak yayasan atau instansi dan juga kerjasama dengan pemerintah yang mengimplementasikan wakaf tunai maka tidak menutup kemungkinan akan terwujudnya perbaikan ekonomi masyarakat di Indonesia. Beberapa lembaga yang sudah berkembang dengan mengimplementasikan wakaf tunai yang dikelola secara produktif seperti Dompet Dhuafa Republika dan Pondok Modern Darussalam Gontor.

Dengan demikian jika wakaf tunai dikelola secara produktif atau dalam sektor produktif maka akan membantu umat/masyarakat dalam perekonomiannya. Dengan cara menahan pokok wakafnya dan memberikan hasilnya kepada masyarakat, sehingga eksistensi substansi wakaf tetap terjaga dan masyarakat bisa menikmati hasil dan manfaatnya. 


\section{Daftar Pustaka}

Al-A nshori, A bi Yahya. 1992. Fathul al- Wahab, Jus 1 Indonesia: Daar alIhya al-Kitab al-arabiyyah.

A nshori, A bdul Ghofur. 2005. Hukum dan Praktik Perwakafan di Indonesia, Yogyakarta: Pilar M edia.

Basyir, A chmad A zhar dan Rachmad Djatnika, dalam Imam Suhandi. 2002. Wakaf untuk K esejahteraan U mat, Yogyakarta: PT. Dama B hakti Prima Yasa.

Departeman A gama RI. 2004. Undang Undang Nomor 41 Tahun 2004 tentang Wakaf.

Direktorat Jendral Pemberdayaan Wakaf. 2007. Pedoman Pengelolaan Wakaf Tunai. Jakarta: Direktorat Jendral Pemberdayaan Wakaf.

A I-K hatib, M uhammad, t.t. Al-Iqna', Darul Ma'arifah, Bairut.

Muzarie, Mukhlisin. 2011. Sukses M emberdayakan Wakaf di Pesantren Modern Gontor. Cirebon: P3I STAI.

Tim Dirjen Bimas Islam dan Penyelengaraan Haji Depag-RI. 2005. Pedoman Pengelolaan Wakaf Uang, Jakarta: Direktorat J enderal Pengembangan Zakat dan Wakaf Direktorat Bimbingan Masyarakat Islam dan Penyelenggaraan $\mathrm{H}$ aji.

U mar Chapra., M. 2001. The Future of Economic and Isamic Perpective, Jakarta: Shariah Economic and Banking Institute.

Wadjdy, Farid dan M ursyid. 2007. Wakaf dan Kesejahteraan U mat "Filantropi Islam yang Hampir Terlupakan. Yogyakarta: Pustaka Pelajar. 